\title{
Complete methodology to resist in mechanism longwall mine 6\# at Nam Mau Coal Company
}

\author{
Hung Phi Nguyen ${ }^{1,}{ }^{*}$, Khai Cao Nguyen ${ }^{1}$, Tung Mạnh Bui ${ }^{1}$, Trung Quang Lai ${ }^{2}$, Thang \\ Van Tran ${ }^{2}$ \\ ${ }^{1}$ Faculty of Mining, Hanoi University of Mining and Geology, Vietnam \\ 2 Vinacomin - Mong Duong Coal Joint Stock Company, Vietnam
}

\begin{abstract}
ARTICLE INFO
ABSTRACT

Article history:

Received $15^{\text {th }}$ Oct. 2019

Revised $26^{\text {th }}$ Jan. 2020

Accepted 28 $8^{\text {th }}$ Feb. 2020

Keywords:

Mechanized longwall,

working times,

scheme of the production

cycle.

Geological condition of 6\# at Nam Mau coal mines is very complicated for mechanism longwall method, specialy was cause of is the cause of difficulties in moving hydraulic support, so it is necessary to have appropriate reform solutions for the support equipment to operate effectively. The result of dynamic field measurements at the site shows that the maximum support pressure is from $5 \div 10 \mathrm{~m}$ in front of the mechanism longwall. The coal seam area is located close to the working face due to the influence of the support pressure and beyond the durable limit which was in an unconsolidated state, so it is possible to cause the mirror landslide and topping out. Calculation results show that the distance of $15 \mathrm{~m}$ against advance reinforcement at the junction of the furnace head and foot furnace as designed. The results of the study of the distribution of surrounding longwall face pressure, length of longwall need longer 40 meters.
\end{abstract}

Copyright (C) 2020 Hanoi University of Mining and Geology. All rights reserved.

${ }^{*}$ Corresponding author

E-mail: nguyenphihung@humg.edu.vn

DOI: 10.46326/JMES.2020.61(1).13 


\title{
Tạp chí Khoa học Kỹ thuật Mỏ - Địa chất
}

Trang điện tử: http://tapchi.humg.edu.vn

\section{Giải pháp nâng cao hiệu quả chống giữ cho lò chợ cơ giới hóa vỉa 6 mỏ than Nam Mẫu}

\author{
Nguyễn Phi Hùng 1, ${ }^{*}$, Nguyễn Cao Khải ${ }^{1}$, Bùi Mạnh Tùng ${ }^{1}$, Lại Quang Trung ${ }^{2}$, Trần \\ Văn Thắng 2
}

${ }^{1}$ Khoa Mỏ, Trường Đại học Mỏ - Địa chất, Việt Nam

2 Công ty cổ phần Than Mông Dương - TKV, Việt Nam

THÔNG TIN BÀI BÁO

TÓM TẮT

\section{Quá trình:}

Nhận bài 15/10/2019

Sửa xong $26 / 01 / 2020$

Chấp nhận đăng 28/02/2020

\section{Tù̀ khóa:}

Lò chợ cơ giới hóa,

Thời gian hoạt động,

Tổ chức chu kỳ.
Trong quá trình khấu gương lò chơ vỉa 6 mỏ than Nam Mẫu gặp điều kiện địa chất phức tạp, gây nhiều khó khăn cho công tác khai thác, dần đến hiệu quả khai thác không cao Một số nguyên nhân như gương than thường xuyền bi vò nhàu, xuất hiện nhiều mặt trượt dài $3 \div 5 \mathrm{~m}$, dễ tut lở, kéo theo đá vách sập đổ tràn vào trước gương lò chợ trong quá trình khai thác, việc xử lý lở gưong, rỗng nóc rất khó khănn, lò chợ thường xuyên phải thực hiện khấu thủ công. Góc dốc lò chợ dốc về phía giữa chợ, dẫn đến các giàn chống phía đầu và phía chân có xu hướng trôi vào giữa lò chợ gây kẹt giàn chống và khi góc dốc lò chợ lớn hơn 200 theo hướng dốc, làm các giàn chống, máng cào lò chợ bi trôi xuống lò chân, mất nhiều thời gian căn chỉnh để đưa về trạng thái ban đầu. Để hạn chế những ảnh hưởng tiêu cực tù̀ điều kiện đia chất mỏ và nâng cao sản lượng khai thác cần thiết phải có nhưng giải pháp chống giũ phù hợp phục vụ công tác khai thác nhịp nhàng hơn. Kết quả đo đạc dịch động tại hiẹn trường cho thấy áp lực tựa lớn nhất nằm tại vi trí tù̀ $5 \div 10 \mathrm{~m}$ trước gưong khai thác. Khu vực vía than nằm sát gương khai thác do chiu ảnh hương của áp lực tựa và vượt qua giới hạn bền đã ở trong trạg thái bở rời nên có khả năng gầy ra hiện tượng lở gương và tưt nóc. Kết quả tính toán thấy rằng khoảng cách $15 \mathrm{~m}$ chống tăng cường tiển trước tại ngã ba lò đầu và lò chân như theo thiết kế.

\section{Mở đầu}

Khả năng áp dụng công nghệ khai thác và hiệu quả thực hiện công nghệ phụ thuộc rất lớn vào điều kiện địa chất mỏ như: mức độ phá huỷ kiến tạo, đặc điểm các vỉa than (chiều dày, góc dốc vỉa

\section{${ }^{*}$ Tác giả liên hệ}

E - mail: nguyenphihung@humg. edu.vn DOI: 10.46326/JMES.2020.61(1).13 và độ ổn định vỉa; chiều dày, số lượng và độ ổn định của đá kẹp trong vỉa than, tính chất của than). Tính chất của đá vách, trụ vỉa (tính chất cơ lý, mức độ phân lớp, nứt nẻ, ngậm nước), độ chứa khí của vỉa than,... (Đỗ Mạnh Phong, 2007).

\section{1. Ảnh hưởng của cấu tạo vỉa than}

Điều kiện khai thác vỉa 6 có chiều dày vỉa than

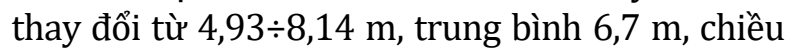


dày riêng than từ $4,8 \div 7,62 \mathrm{~m}$, trung bình $6,32 \mathrm{~m}$ số lớp đá kẹp từ $2 \div 5$ lớp, chiều dày đá kẹp từ $0,13 \div 0,52 \mathrm{~m}$, trung bình $0,33 \mathrm{~m}$. Góc dốc của vỉa than thay đổi từ $1 \div 20^{\circ}$ trung bình $5^{\circ}$. Quan trắc thực tế cho thấy vỉa than được cấu tạo bởi nhiều phân lớp mỏng với chiều dày từ $0,04 \div 0,4 \mathrm{~m}$ với mặt phân lớp phẳng, nhẵn. Than chủ yếu là loại antraxit, cứng. Xen kẹp trong vỉa than là một số lớp kẹp (thường từ $2 \div 3$ lớp) có chiều dày từ $0,04 \div 0,3 \mathrm{~m}$. Đá kẹp tồn tại ở dạng các lớp mỏng, các thấu kính (thành phần kẹp là sét kết, sét than và bột kết), dễ tách lớp nên thuận lợi cho công tác hạ trần than hiệu quả. Tuy nhiên, sự xuất hiện của các lớp kẹp trong vỉa than làm giảm độ ổn định của nóc lò chợ (Phạm Ngọc Huynh, 2016; Hoàng Hùng Thắng, 2012).

Mức độ ổn định của vỉa than cũng góp phần quan trong đến quá trình khai thác lò chợ. Như đã trình bày, quan trắc thực tế trong quá trình áp dụng cho thấy trụ của vỉa than biến đổi lớn đã hạn chế đến hiệu quả làm việc của đồng bộ thiết bị cơ giới hóa khai thác. Trong thời gian áp dụng gương lò chợ luôn tiến theo hướng cắm xuống dưới nên các máng cào và giàn chống thường có hiện tượng trôi trượt, gây khó khăn cho công tác nắn luồng gương. Ngoài ra, do trụ vỉa than cũng biến đổi dọc theo hướng dốc và trũng vào giữa gương lò chợ đã tạo thành khu chứa nước phải dùng bơm mới thoát được, cũng từ đó xảy ra hiện tượng các giàn chống có xu hướng trôi trượt vào giữa lò chợ, gây nên tình trạng các giàn chống bị sát, gây khó khăn khi di chuyển, cụm dẫn hướng của giàn chống thường xuyên bi gẫy (Nông Việt Hùng, 2018; Viện KHCN Mỏ, 2010; JM, 2011).

\section{2. Ảnh hưởng của đặc điểm cấu tạo và tính chất co lý của đá vách vỉa}

Vách giả là sét kết dạng thấu kính phân bố không đều, chiều dày $0,14 \div 0,23 \mathrm{~m}$, dễ sập lở. Cường độ kháng nén $\left(\sigma_{n}\right)$ trung bình khoảng từ $8,5 \div 24,4 \mathrm{MPa}$. Trọng lượng thể tích từ $2,56 \div 2,71$ $\mathrm{T} / \mathrm{m}^{3}$, trung bình $2,64 \mathrm{~T} / \mathrm{m}^{3}$. Vách trực tiếp là lớp bột kết phân bố đều dày từ $5 \div 25 \mathrm{~m}$, trung bình 17 $\mathrm{m}$, vách thuộc loại không ổn định đến ổn định trung bình, cường độ kháng nén $24,4 \div 62,2 \mathrm{MPa}$, trung bình 45,6 $\mathrm{MPa}$. Trọng lượng thể tích từ $2,55 \div 2,70 \mathrm{~T} / \mathrm{m}^{3}$, trung bình $2,59 \mathrm{~T} / \mathrm{m}^{3}$. Lực dính

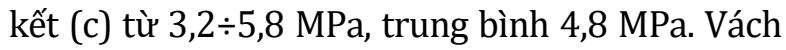
cơ bản chủ yếu là bột kết xen kẹp cát kết, phân bố đều, dày $4 \div 22 \mathrm{~m}$, sập đổ trung bình đến khó sập

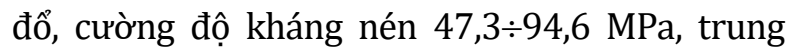
bình 65,7 MPa (Viện KHCN Mỏ, 2010).

Kết quả khảo sát quan trắc tại gương và nóc lò chợ thấy rằng mật độ các khe nứt trong cùng một hệ $(\lambda)$ từ $2 \div 6(q=n / S$ trong đó $n$ là số hệ thống khe nứt; $\mathrm{S}$ diện tích khảo sát có xuất hiện khe nứt) và của nhiều hệ (Jv) từ $6 \div 16 \mathrm{KN} / \mathrm{m}^{3}$. Khoảng cách các khe nứt dao động từ $0,05 \div 0,5 \mathrm{~m}$, nhưng khu vực phía dưới lò chợ (đoạn từ giàn số 10 đến khoảng giàn số 40) khoảng cách các khe nứt thưa hơn, dao động từ $0,1 \div 1,0 \mathrm{~m}$. Mặt phân lớp phân phiến nhẵn phẳng nên khi bị ngấm nước dễ tách chẽ, gãy khúc theo mặt khe nứt (Nông Việt Hùng, 2018; Viện KHCN Mỏ, 2010).

Hiện tượng sập lở của lớp than nóc phát triển ngay sát phía sau giàn chống tự hành. Các khối than nóc sập lở ngay sau khi di chuyển giàn chống với kích thước chủ yếu $10 \times 20 \times 20 \mathrm{~cm}$, đôi chỗ lên $40 \times 25 \times 30 \mathrm{~cm}$. Do đó công tác thu hồi than hạ trần tương đối thuận lợi. Thông thường lớp vách giả sập đổ ngay cùng với sập đổ của lớp than nóc. Hiện tượng sập lở của đá vách trực tiếp phát triển chậm hơn so với lớp than nóc. Các khối đá sập lở với kích thước $130 \times 50 \times 120 \mathrm{~cm}, 70 \times 25$ $\times 30 \mathrm{~cm}, 70 \times 20 \times 40 \mathrm{~cm}$ và chồng xếp lên nhau tạo ra nhiều lỗ hổng lớn. Nhiều chỗ các lỗ hổng sâu tới $0,8 \div 2,1 \mathrm{~m}$ còn thông thường từ $0,4 \div 1,2 \mathrm{~m}$. Hiện tượng rỗng nóc tồn tại một thời gian, khi một vài lần chuyển luồng mới xảy ra hiện tượng sập đổ kế tiếp của tập cát kết.

Trong thời gian đầu áp dụng và trước khi bước gãy ban đầu của đá vách, do áp lực lớn và chiều dày trần than nóc mỏng (dày khoảng $0,5 \div 1,5 \mathrm{~m}$ ), nên đoạn lò, trần than và một số tập lớp đá vách giáp via sập đổ, tràn vào không gian lò chợ, nóc lò luôn trong tình trạng bị rỗng, việc di chuyển giàn chống và máng cào rất khó khăn, khi đẩy máng tiến gương, giàn chống lùi lại luồng phá hỏa. Hiện tượng này hay xảy ra trong quá trình áp dụng, đặc biệt sau khi phá hỏa ban đầu.

\section{Xác định áp lực mỏ khu vực khai thác lò chợ cơ giới hóa}

Sơ đồ tính toán bước sập đổ của tập lớp đá vách cơ bản trong quá trình biến dạng do ảnh hưởng của khai thác lò chợ thể hiện trên Hình 1.

Tập lớp vách cơ bản sập đổ đặc trưng dưới dạng bản dầm công sơn. Phía sau gương khai thác, bản dầm này tạo ra tải trọng $\mathrm{q}_{1}$ được xác định trên cơ sở tự trọng của vách cơ bản và khối lượng các 
tập lớp (độ bền vững của từng lớp trong tập lớp nhỏ hơn độ bền vững của vách cơ bản). (Đố Mạnh Phong, 2007; Hong, 2014).

Để theo dõi diễn biến áp lực trong gương khai thác, đã sử dụng các kết quả hiển thị trên các đồng hồ đo áp lực tức thời của các giàn chống tự hành Vinaalta. Các trạm quan trắc đo áp lực mỏ trong lò chợ được bố trí cách nhau $9 \mathrm{~m} /$ trạm, tương ứng với 6 dàn. Các trạm đo được đánh số thứ tự bằng sơn trắng ghi trực tiếp lên giàn chống theo chiều từ chân lên đầu lò chợ với tổng số các trạm đo là 12 trạm. Sơ đồ bố trí các trạm đo áp lực trong lò chợ xem Hình 5.

Quá trình theo dõi số liệu áp lực trong lò chợ I - V6 - 1 được thực hiện 1 lần/ca. Số liệu được lấy sau khi di chuyển giàn chống sang luồng khấu mới ổn định. Thứ tự các trạm quan trắc áp lực mỏ từ 1 đến 12 , tương ứng với các giàn chống trong lò chợ là: giàn số $1,6,12,18,24,30,36,42,48,54,60$ và giàn số 66.

Kết quả đo đạc áp lực mỏ dọc lò chợ cơ giới hóa cho thấy tải trọng tác động lên các giàn chống tự hành cũng phân bố không đồng đều theo chiều dốc lò chợ. Trong $20 \mathrm{~m}$ theo phương giai đoạn đầu quá trình áp dụng thử nghiệm, áp lực đất đá tác động lên đoạn lò chợ từ giàn 7 đến giàn 40 (khu vực vách phía sau luồng phá hỏa không sập đổ triệt để) thường lớn hơn đoạn lò chợ từ giàn 41 đến giàn số 68. Phân bố tải trọng tác dụng lên giàn chống tự hành trong $30 \mathrm{~m}$ khai thác thử nghiệm theo phương đầu tiên, thấy rằng áp lực khu vực lò chợ được phân bố không đồng đều, cao ở lò đầu, lò chân và giữa lò chợ, chi tiết trên không gian ba chiều tại Hình 2.

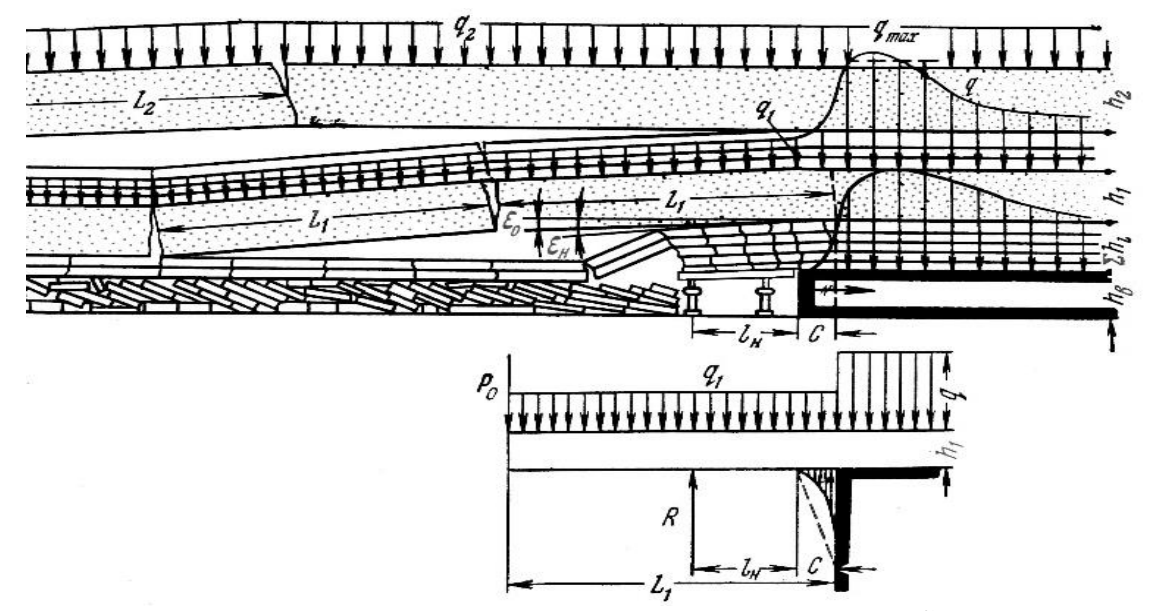

Hình 1. Mô hình tính toán bước sập đổ của tập lớp đá vách cơ bản (Đỗ Mạnh Phong, 2007; Chan, 2014; Hong, 2014).

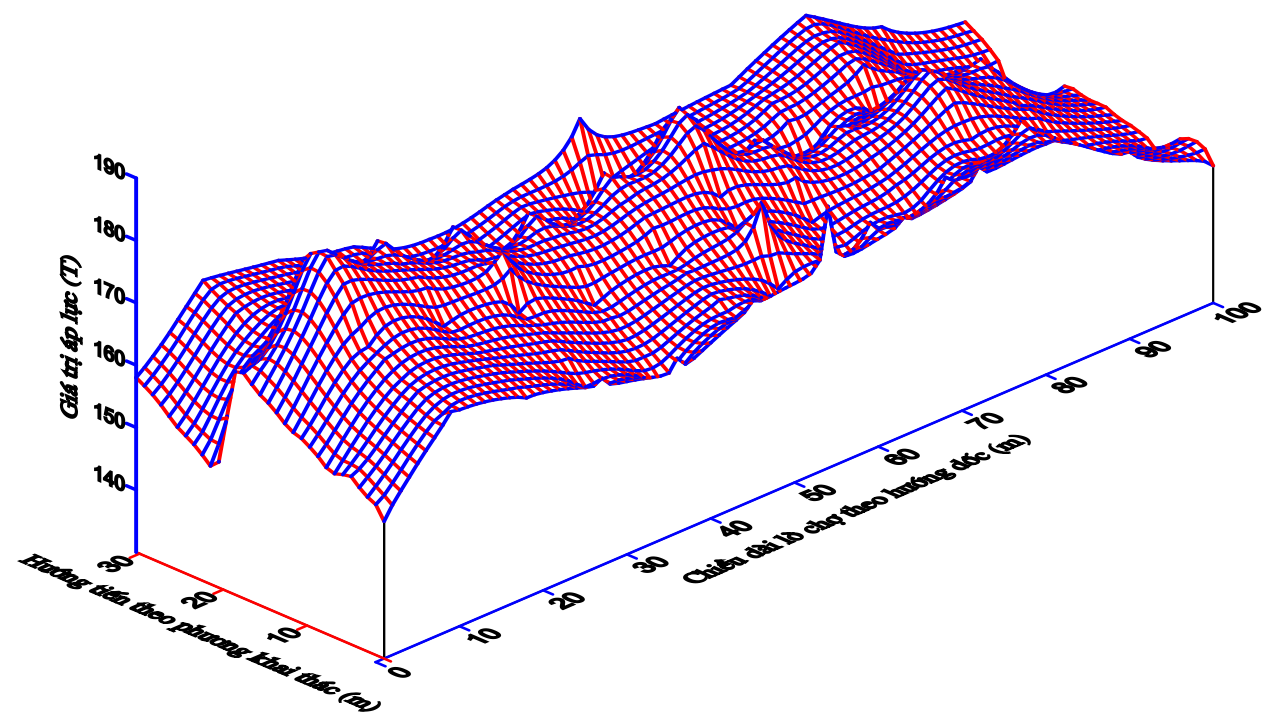

Hình 2. Kết quả đo đạc áp lực thực tế tại lò chợ vỉa 6. 
Phân tích chi tiết biểu đồ phân bố áp lực mỏ lên giàn chống số 36 chỉ ra rằng, tải trọng đất đá tác động lên giàn chống tăng dần theo tiến độ của gương khai thác từ 88 tấn/giàn tại thượng khởi điểm lên đến 180 tấn/giàn tại khoảng cách $20 \mathrm{~m}$ theo phương, sau đó giảm đột ngột xuống còn 112 tấn/giàn, và biến đổi lên xuống có tính chu kỳ với chiều dài theo phương $2,0 \div 3,0 \mathrm{~m}$, tải trọng một giàn chống dao động $160 \div 170$ tấn/giàn. Kết quả đo đạc phù hợp với diễn biến sập đổ của đá vách phía sau luồng phá hỏa tính từ thượng khởi điểm đến vị trí đá vách sập đổ chèn kín khoảng không đã khai thác và các bước sập đổ thường kỳ theo sau bước gãy ban đầu. Hình 4 trình bày diễn biến tải trọng tác dụng lên giàn chống số 36 từ thượng khởi điểm đến vị trí $30 \mathrm{~m}$ khai thác theo phương.

Sau thời điểm vách trực tiếp gãy, áp lực mỏ phân bố dọc theo hướng dốc lò chợ phân bố đồng đều hơn và dao động từ $162 \div 170$ tấn/giàn. Hình
5 mô tả sự phân bố áp lực lên các giàn chống dọc tuyến gương lò chợ.

\section{Hoàn thiện hộ chiếu chống giữ lò chợ cơ giới hóa}

Phương pháp ước tính tải trọng cho rằng khả năng mang tải hợp lý $\mathrm{P}(\mathrm{kN})$ của vì chống phải chịu toàn bộ áp lực (Q1) từ đá vách trực tiếp và trong khu vực đỉnh kiểm soát, đồng thời phải chịu sự hình thành tải trọng ước tính (Q2) bổ sung khi vách cơ bản có áp lực tĩnh.

$$
P=Q 1+Q 2=\Sigma(\text { hi.li. } \gamma i)+Q 2,\left(\mathrm{kN} / \mathrm{m}^{2}\right)
$$

Trong đó: $h i, l i, \gamma i$ lần lượt là độ dày, khoảng cách mái treo và mật độ khối của vách trực tiếp.

Khi vách trực tiếp bị hở theo sự dịch chuyển của vì chống, li bằng cự ly đỉnh kiểm soát $\mathrm{lm}$, cường độ vì chống $p\left(\mathrm{kN} / \mathrm{m}^{2}\right)$ hợp lý của lò chợ nên là:

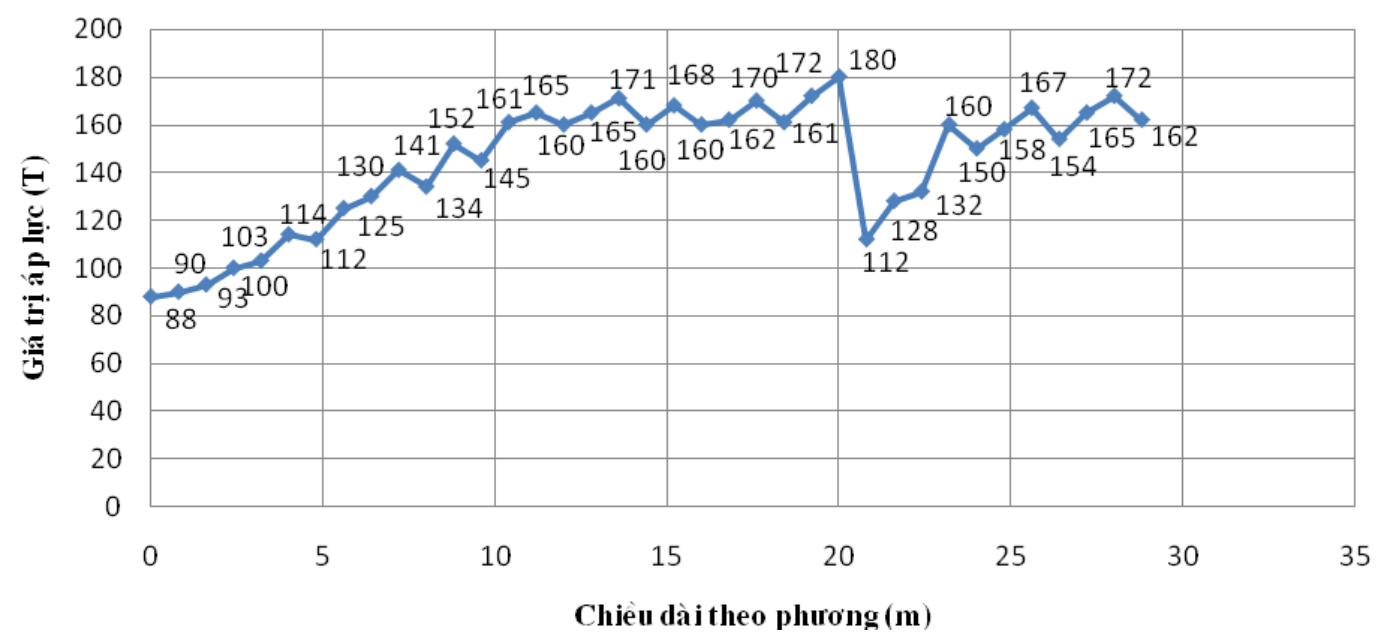

Hình 3. Phân bố áp lực mỏ lên giàn chống số 36 theo phương khai thác.

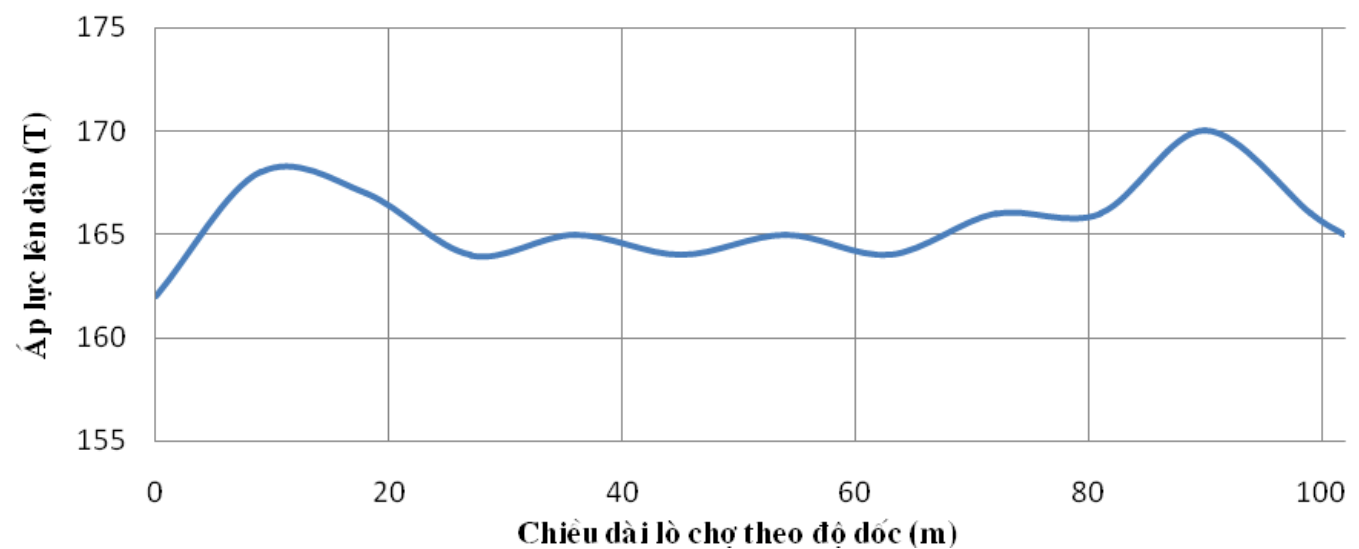

Hình 4. Phân bố áp lực lên các giàn chống dọc tuyến gương lò chợ. 


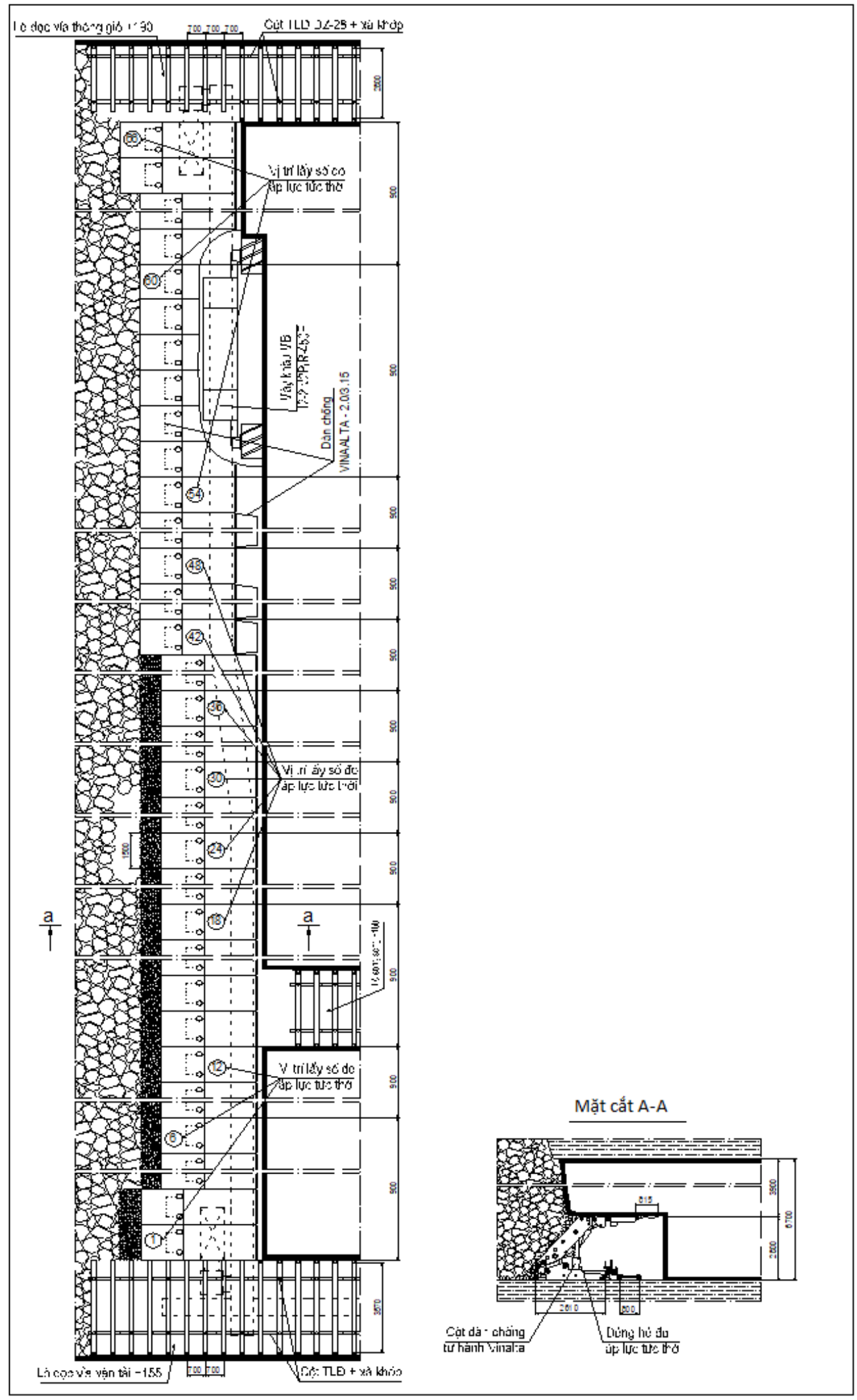

Hình 5. Sơ đồ bố trí trạm đo áp lực trong lò chọ̣ I - V6 - 1 . 


$$
P=\Sigma(\text { hi. } \gamma i)+Q 2 / L m
$$

Do tải trọng ước tính Q2 của vách cơ bản khó tính toán chính xác, có thể lấy tải trọng vì chống khi không có áp lực tĩnh làm tải trọng ước tính của vách trực tiếp, rồi nhân với hệ số áp lực động n khi có áp lực tĩnh, để được:

$$
P=n . \Sigma \text { (hi. } \gamma \text { i) }
$$

Nếu hệ số giãn nở của vách trực tiếp là $2,25 \div 2,5$, hệ số áp lực động không vượt quá 2 .

Từ cơ sở lý thuyết kết hợp với thực tế quan sát hiện trường có thể xây dựng hộ chiếu chống và chống tăng cường trong lò chợ như sau.

\subsection{Hộ chiếu chống lò chộ}

Vai trò của giàn chống là đảm bảo an toàn không gian khai thác và đẩy máng cào gương, thu hồi than hạ trần, do đó khi sử dụng giàn chống phải tuân thủ chặt chẽ quy trình công nghệ khai thác lò chợ cơ giới và các quy trình vận hành, bảo dưỡng. Khi di chuyển giàn chống sang vị trí mới, cột chống phải vuông ke, các giàn chống phải thẳng hàng, khoảng chênh cao giữa các giàn phải đảm bảo điều kiện kỹ thuật. Công tác xúc dọn than trước giàn chống phải được thực hiện thường xuyên trong quá trình sản xuất nhằm tạo thuận lợi khi di chuyển giàn chống.

Theo thiết kế trong lò chợ, giàn chống đầu tiên và cuối cùng phải chống tụt lại phía sau tiến độ 0,8 $m$ để che chắn bộ phận truyền động đầu và đuôi máng cào gương, vô hình chung sẽ tạo ra khe hở giữa các giàn chống này với giàn liền kề dẫn đến đá phá hoả theo các khe hở này tràn vào gương. Để xử lý tình trạng trên cần thiết phải gia công thanh truyền có chiều dài ngắn hơn $(L=0,4 \mathrm{~m})$. Như vậy khe hở sẽ được giảm từ $0,8 \mathrm{~m}$ xuống 0,5 hoặc $0,4 \mathrm{~m}$.

Xếp cũi lợn hoặc vì chống tăng cường ngã ba đầu và chân chợ, nhằm mục đích ngăn chặn đất đá phá hỏa tràn vào lò dọc vỉa và giảm bớt một phần áp lực tác dụng lên giàn chống ngoài cùng phía đầu, chân chợ.

\subsection{Hộ chiếu chống tăng cường lò dọc vỉa}

Kết quả đo đạc dịch động tại hiện trường cho thấy áp lực tựa lớn nhất nằm tại vị trí từ $5 \div 10 \mathrm{~m}$ trước gương khai thác. Khu vực vỉa than nằm sát gương khai thác do chịu ảnh hưởng của áp lực tựa và vượt qua giới hạn bền đã ở trong trạng thái bở rời nên có khả năng gây ra hiện tượng lở gương và tụt nóc. Từ kết quả nghiên cứu và trên cơ sở thực nghiệm có thể khẳng định khoảng cách $15 \mathrm{~m}$ chống tăng cường tiến trước tại ngã ba lò đầu và lò chân như theo thiết kế.

Tuy nhiên, do ngã ba giữa gương lò chợ cơ giới hóa và các đường lò chuẩn bị được chống giữ bằng cột thủy lực đơn và xà hộp HDFPC - 4400 nên thường xuyên là khu vực khó khăn và tốn nhiều thời gian chống giữ. Do đó trong thời gian tới cần thiết nghiên cứu chế tạo các phù hợp với điều kiện đặc trưng khu vực để chống giữ đoạn ngã ba giữa chân và đầu lò chợ đảm bảo đủ không gian bố trí đầu máng cào lò chợ và đuôi của cầu chuyển tải lò dọc vỉa.

\section{Kết luận}

Căn cứ trên cơ sở kết quả nghiên cứu phân bố áp lực mỏ xung quanh gương lò chợ (Hình 2,3 và Hình 4) cho thấy chiều dài vùng ảnh hưởng của áp lực tựa dọc theo gương khai thác nằm trong khoảng $15 \div 20 \mathrm{~m}$ tính từ các đường lò dọc vỉa. Ngoài khu vực ảnh hưởng trên, áp lực tác động lên gương lò chợ luôn duy trì ổn định. Tuy nhiên, chiều dài lò chợ khai thác còn phụ thuộc một số yếu tố khác như chiều dài theo phương khu vực khai thác, hộ chiếu chống giữ đường lò chuẩn bị, hiện trang sơ đồ khai thông chuẩn bị v.v.. Khi chiều dài theo phương khu vực khai thác nhỏ, gương lò chợ cơ giới hóa có chiều dài lớn thì chi phí cho công tác lắp đặt và chuyển diện khai thác lớn, dẫn đến hiệu quả khai thác không cao.

\section{Tài liệu tham khảo}

Akande, J. M. and Saliu M. A., (2011). Design of a Powered Support System in Enugu Coal Mine. Journal of Emerging Trends in Engineering and Applied Sciences (JETEAS) 2 (6). 1083 - 1089.

Chandan Kumar, 2014. Behavior of Shield Support in Longwall Mining. Thesis Department of Mining Engineering National Institute of Technology Rourkela.

Đỗ Mạnh Phong, Vũ Đình Tiến, (2007). Áp lực mỏ hầm lò. Nhà xuất bản Giao thông Vận tải.

Hoàng Hùng Thắng, Bùi Đình Thanh, Vũ Trọng Hiệt, (2012). Vấn đề xác định áp lực trong lò chợ cơ giới hoá khi khai thác vỉa mỏng, dầy trung bình dốc đứng. Tạp chí Năng lượng Việt Nam. 
Hongpu Kang, (2014). Support technologies for deep and complex roadways in underground coal mines: a review. International Journal of Coal Science \& Technology 1(3). 261 - 277.

Nông Việt Hùng, (2018). Nghiên cứu hoàn thiện một số thông số công nghệ khai thác lò chợ cơ giới hóa đồng bộ hạ trần than ở vỉa dày, dốc thoải và nghiêng tại các mỏ hầm lò vùng quảng ninh. Luận án tiến sĩ kỹ thuật. Đại học Mỏ - Địa chất.
Electrohydraulic control systems for powered roof supports in hazardous conditions of mining tremors.

Viện Khoa học Công nghệ mỏ, (2006 2010). Nghiên cứu lựa chọn công nghệ cơ giới hóa khai thác và thiết kế, chế tạo loại giàn chống tự hành phù hợp áp dụng cho điều kiện địa chất các vỉa dày độ dốc đến $35^{0}$ tại vùng Quảng Ninh. Chương trình trọng điểm cấp Nhà nước giai đoạn $2006 \div 2010$. 